"Synthesis of information control devices which are transferred to diagnostic network with package composition"

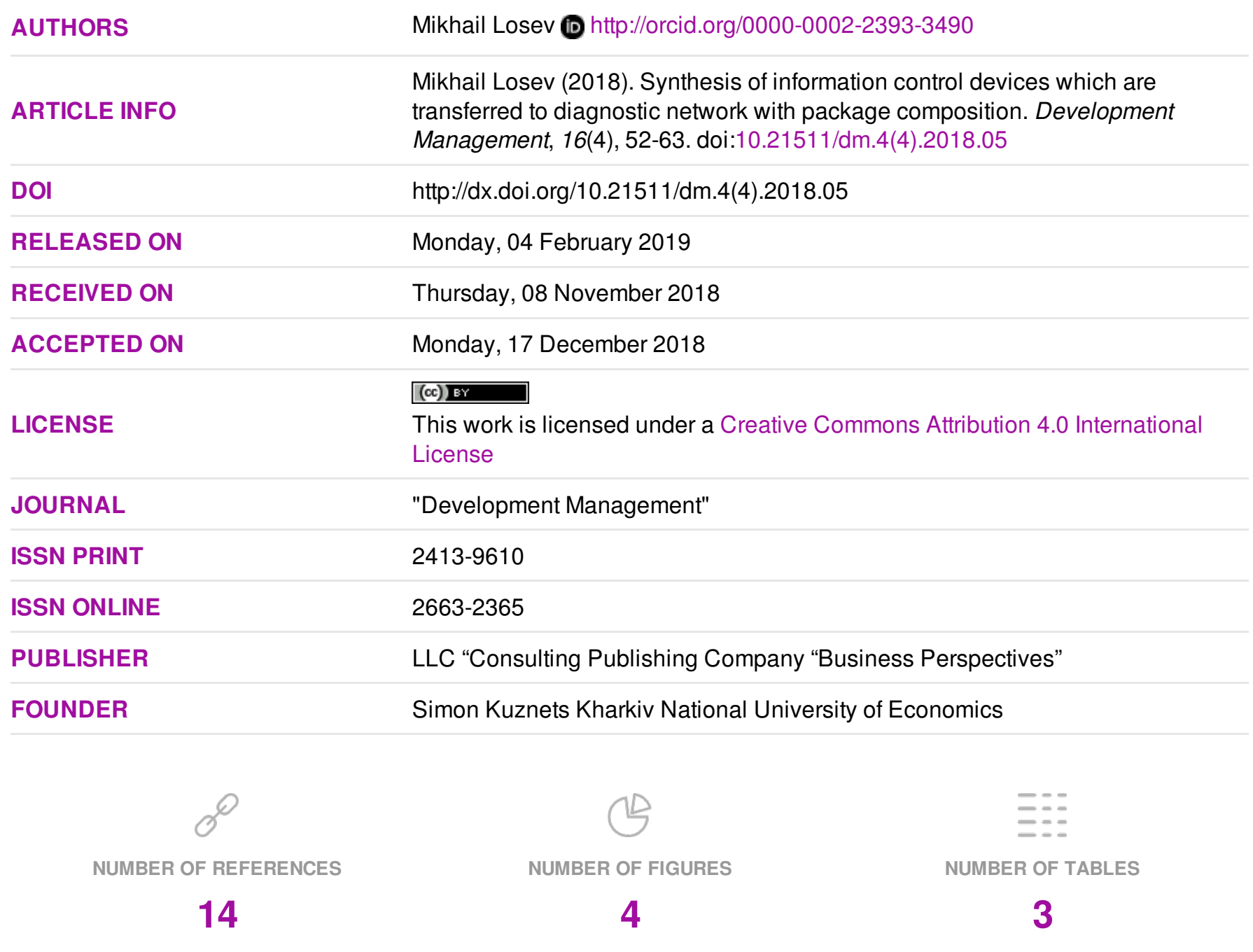

(C) The author(s) 2022. This publication is an open access article. 


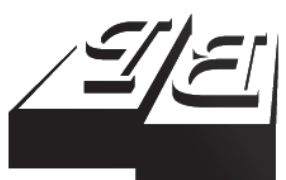

BUSINESS PERSPECTIVES

Publisher:

LLC "CPC "Business Perspectives" Hryhorii Skovoroda lane, 10, Sumy, 40022, Ukraine www.businessperspectives.org

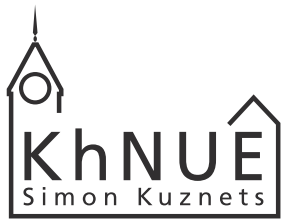

\section{S. KUZNETS KHNUE}

Founder:

Simon Kuznets Kharkiv National University of Economics, Nauky avenue, 9-A, Kharkiv, 61166, Ukraine

http://www.hneu.edu.ua/

Received on: 8th of

November, 2018

Accepted on: 17th of

December, 2018

\section{(C) Mikhail Losev, 2018}

Mikhail Losev, Ph. D., Associate professor, Simon Kuznets Kharkiv National University of Economics, Ukraine.

\title{
SYNTHESIS OF INFORMATION CONTROL DEVICES WHICH ARE TRANSFERRED TO DIAGNOSTIC NETWORK WITH PACKAGE COMPOSITION
}

\begin{abstract}
In the context of growing requirements for the reliability of information and a reduction in the time of data delivery, the urgent task is the development of simple and effective means of control as a process of transmission of information and equipment in distributed systems. The problem of diagnosing the efficiency of distributed systems in data exchange networks with packet switching is considered in the paper.

The proposed approach to the synthesis of data control devices is most effective in verifying the transmission of a multitude of packet messages over a datagram channel in time division mode and can be used in digital test device diagnostic systems as an initialization analyzer.

The practical implementation of the proposed approach allows you to create devices that have achieved a significant reduction in hardware costs and simplify the technical implementation of signature analyzers. In this case, it is not necessary to store the input information, which provides the possibility of using different characteristic of polynomials, by automatically generating this information in the device. Parallel processing of message packets or diagnostic information allows to increase the speed of analyzers, with reception of signatures that equal the signature of a single-channel analyzer. Examples of synthesis of multichannel signature analyzers that are capable of high-speed data reliably process information, localize errors in the information input sequence and determine the number of the false packet in the message or the device from the group of verifiable devices are given.
\end{abstract}

Keywords

JEL Classification

М.Ю. Лосєв (Україна) test control, technical diagnostics, irreducible and primitive polynomials, shift registers, signature analysis, interferenceprotected code, information sequence

\section{СИНТЕЗ ПРИСТРОЇВ КОНТРОЛЮ ІНФОРМАЦІї, ЩО ПЕРЕДАЄТЬСЯ ДЛЯ ДІАГНОСТУВАННЯ МЕРЕЖ 3 КОМУТАЦІЕЮ ПАКЕТІВ}

\section{Анотація}

В сучасних умовах зростання вимог до зменшення часу обміну інформацією, що передається між об'єктами, а також підвищення достовірності доставки даних абонентам є актуальною задача розроблення простих і ефективних засобів контролю як процесу передачі інформації, так і обладнання в розподілених системах. В роботі розглядається проблема діагностування працездатності розподілених систем в мережах обміну даними з комутацією пакетів. Пропонований підхід до синтезу пристроїв контролю даних найбільш ефективний при перевірці передачі безлічі повідомлень пакетами по дейтаграммному каналу в режимі поділу часу та може використовуватися в якості аналізатора вихідних реакцій у системах тестового діагностування апаратури системи зв'язку.

Практична реалізація запропонованого підходу дозволяє створювати діагностичні пристрої, в яких досягнуто суттєве спрощення технічної реалізації сигнатурних аналізаторів, що значно впливає на зменшення апаратурних витрат. При цьому не потрібно зберігати вхідну інформацію, яка автоматично формується в сигнатурному аналізаторі і забезпечує можливість використання різних характеристичних поліномів. Паралельна обробка пакетів повідомлень або діагностичної інформації дозволяє підвищити швидкодію аналізаторів, з одержанням сигнатур, які дорівнюють сигнатурі одноканального аналізатора при використанні одного й 
того поліному.

Наведені приклади синтезу багатоканальних сигнатурних аналізаторів, які здатні з високою швидкодією достовірно обробляти інформацію, локалізувати помилки в інформаційній вхідній послідовності та визначати номер помилкового пакету в повідомленні або прилад з групи приладів, що перевіряються.

Ключові слова

Класифікація JEL тестовий контроль, технічна діагностика, поліном що неприводиться примітивний поліном, регістри зсуву, сигнатурний аналіз, перешкодозахищений код, інформаційних послідовність

\section{ВСТУП}

Сучасні системи зв’язку мають складну розподілену багаторівневу архітектуру. Часткова відмова апаратури є характерною рисою розподілених систем. Такі відмови відбуваються при збої в одному або в декількох з компонент розподіленої системи, тоді як інші компоненти це може не торкнутися. Часткові відмови в розподілених системах завжди є глобальними, тому що вони так чи інакше, прямо або побічно, чіпають всі їх компоненти і можуть привести до повної втрати працездатності [13].

Створення нового обладнання переслідує мету розширення функціональних можливостей, підвищення його швидкодії в процесі збору і обробки інформації та спрощення технічної реалізації (зменшення об’єму пам'яті тощо). Розширення функціональних можливостей досягається шляхом додавання операцій, які позволяють визначати та виправляти помилки в інформаційних повідомленнях, встановлювати проблемні маршрути в мережі, діагностувати обладнання на основі аналізу або використанням різноманітних поліномів для перевірки реакцій на тестування.

В умовах зростання вимог до зменшення часу обміну інформацією, що передається між объєктами, а також підвищення достовірності доставки даних абонентам $€$ актуальною задача розроблення простих і ефективних засобів контролю як процесу передачі інформації, так і обладнання в розподілених системах. Тому основна мета цього дослідження є удосконалення методики синтезу універсальних, швидкодіючих багатоканальних пристроїв на основі методу сигнатурного аналізу, які дозволяють локалізувати помилки в інформаційних пакетах повідомлень і давати інформацію для діагностування обладнання.

Объєктом дослідження $є$ процес передачі даних і визначення зіпсованих пакетів в повідомленнях.

Предметом дослідження є методи пошуку і діагностування помилок в пакетах повідомлень.

\section{1. ЛІТЕРАТУРНИЙ ОГЛЯА}

Розвиток мережевих технологій істотно підвищує вимоги до ефективності систем передачі даних, включаючи підвищення достовірності передачі і пропускної здатності, завжди привертали увагу фахівців інформаційних технологій і телекомунікацій. Питання оцінки та обгрунтування принципів побудови і розробки методів обміну інформацією в розподілених обчислювальних мережах розглянуті в роботах $[5-8,14]$. При цьому розглядаються концепції побудови систем динамічного управління інформаційним обміном. Наводяться рекомендації для підвищення ефективності роботи апаратно-програмного забезпечення відомих і перспективних обчислювальних мереж.В процесі передачі даних дуже високі вимоги пред>являються до правильності доставки повідомлень. Задоволення цих вимог грунтується на використанні зворотного зв язку в поєднанні з перешкодостійкими кодами, яким присвячені класичні роботи $[1,12]$.

Сигнатурний аналіз $є$ одним 3 таких напрямків використання циклічних кодів. Він успішно застосовується для перевірки електронного цифрового обладнання на працездатність. Але цей метод може бути застосований для контролю передачі інформації. Використання сигнатурного аналізу було вперше обгрунтовано в роботі [3]. 3 метою підвищення швидкодії і розширення функціональних 
можливостей сигнатурних аналізаторів в сучасних розробках $[2,4,9-11]$ пропонуються багатоканальні сигнатурні аналізатори. Однак поліпшення їх можливостей щодо виявлення та локалізації помилок у даних призводить до значного збільшення інформаційної надмірності або ускладнення технічної реалізації. Незважаючи на велику кількість прикладних розробок багатоканальних приладів контролю даних в $[2,4,9-11]$ відсутній єдиний підхід до їх розвитку та забезпечення широких функціональних можливостей.

Матриця станів сигнатурного аналізатора, будується на основі характеристичного полінома над полем Галуа GF(2). При цьому кожний стовбець цієї матриці визначається відповідно виразу [12]:

$$
h_{i}=S^{i} \cdot h_{0}, i=0,1, \ldots \mathrm{W},(1)
$$

де $\mathrm{h}_{\mathrm{i}}$ - i-й стовбець матриці станів $\mathrm{H}, \mathrm{w}$ - кількість стовбців матриці станів, $\mathrm{h}_{0}=\|10 \ldots 0\|^{\mathrm{T}}$ - нульовий стовбець матриці станів, $S$ - супроводжуюча матриця, яка однозначно описує характеристичний поліном [1].

$$
P(x)=a_{n} x^{n} \oplus a_{n-1} x^{n-1} \oplus . a_{i} x^{i} . \oplus a_{1} x^{1} \oplus 1,
$$

де $a_{i} \in\{0,1\}$ - коефіцієнти характеристичного поліному.

Процес отримання сигнатури для вхідної послідовності $v(t)$ можна представити з допомогою виразу:

$$
\operatorname{sigv}(t)=\sum_{i=0}^{w} S^{i} v_{i} h_{0},(3)
$$

де $\Sigma$ - сума за модулем два, $v_{i}$ - i-й елемент вхідної послідовності, w - кількість елементів вхідної послідовності. Вираз (3) можна перетворити до наступного вигляду:

$$
\operatorname{sig} v(t)=\sum_{i=0}^{w} h_{i} v_{i}
$$

Таким чином, сигнатура вхідної послідовності дорівнює сумі тих стовбців матрицістанів, які відповідають ненульовим елементам $v_{i}$. Отримання тільки сигнатури ще не дозволяє пристроям виконувати діагностичні функції, які призначенні для визначення помилок, а також їх виправлення.

\section{2. МЕТА ДОСЛІДЖЕННЯ}

Метою статті $€$ удосконалення методики синтезу універсальних, швидкодіючих багатоканальних сигнатурних аналізаторів, що дозволяють контролювати повідомлення, локалізувати помилки в інформаційних пакетах і давати інформацію для діагностування обладнання. При цьому результати згорток інформації повинні строго відповідати класичному одноканальному пристрою [3].

\section{3. МЕТОДИ ДОСЛІДЖЕННЯ}

Методи дослідження: метод сигнатурного аналізу, а також методи пошуку і діагностування помилок в пакетах повідомлень.

Моделювання процесу прийому повідомлення.

Управління обміном даними може здійснюватися методами інформаційного забезпечення, методами управління канальними, буферними і тимчасовими ресурсами, а також вибором стратегії розподілу ресурсів (централізованої, ієрархічної, децентралізованої) [8]. При управлінні мережевими ресурсами можна впливати на параметри каналу передачі даних, а також і на структуру інформаційного тракту. Вибір параметрів управління компютерними мережами $є$ важко формалізується завданням і часто 
грунтується на особистих уподобаннях менеджерів і дослідників. Одним з найважливіших напрямків таких досліджень став аналіз ефективності обміну даними в мережах з комутацією пакетів на основі ймовірносно-часових графів [5-8]. Однак всі вони спрямовані на дослідження існуючих правил інформаційного обміну (протоколів). Зміна протоколів можлива на основі застосування нових технологій, методів і засобів передачі і контролю даних.

Підвищення швидкодії пристроїв контролю переданих повідомлень має особливе значення при обміні даними по дейтаграммний каналу, в якому кожен пакет доставляється абоненту і обробляється як самостійне повідомлення. Фази з`єднання і розєєднання відсутні. Після доставки всіх пакетів на приймальній стороні формується повідомлення. Останні дії можуть істотно збільшити час доставки повідомлень при запізненні хоча 6 одного пакету.

Розглянемо можливості розширення діагностичних функцій сигнатурного аналізу.

Припустимо, що інформаційна послідовність передається в сигнатурний аналізатор по группах, по $m$ розрядів в кожній. Тоді вираз (4) можно перетворити до виразу, який наведений нижче:

$\operatorname{sig} 1 v(t)=\sum_{i=1}^{z-1} S^{m(i-1)} \sum_{j=0}^{m-1} S^{j} v_{j},(5)$

де z - кількість тактів роботи приладу.

На першому такті аналізатор обробляє групу розрядів $\left(v_{m(r-1)}, v_{(m+1)(r-1)}, \ldots v_{m r-1}\right)$, а на останньому такті - $\left(v_{0}\right.$ $\left., v_{1}, \ldots, v_{m-1}\right)$. Для того, щоб результат відповідав виразу (12), необхідно сигнатуру першої групи розрядів умножати на матрицю $S^{m(r-1)}$, а результат множення скласти за модулем два зі згорткою наступної групи розрядів, яка попередньо множиться на матрицю $S^{m(r-2)}$. Такі дії повторюються поки буде вводитися вся інформаційна послідовність до останньої групи розрядів.

Виконаємо лінійне перетворення сигнатури (9) за наступним правилом:

$\operatorname{sig} 2 v(t)=\sum_{j=1}^{z} \mathrm{~g}_{\mathrm{j}} \mathrm{S}^{\mathrm{j}-1},(6)$

де $\mathrm{g}_{\mathrm{i}}$ - сигнатура i- ї групи розрядів (пакета).

Таким чином, отримані дві сигнатури або два перевірочних кодових слова $\operatorname{siglv}(t)$ isig2 $v(t)$. В якості контрольної кодової комбінації необхідно використовувати дві еталонні сигнатури (або два контрольних слова) E1 і Е2, які складаються з сукупності еталонів груп розрядів інформаційної послідовності [12]:

$E_{1}=e_{1}+e_{2}+\ldots+e_{z}$,

$E_{2}=e_{1}^{1}+e_{2}^{1}+\ldots+e_{z}^{1}$

де $e_{j}^{l}=e_{j} S^{j-1}$.

Якщо існує помилка, що виявляється, в і-му пакеті, тоді виникнуть зміни в сигнатурі і-го пакету gi, a синдроми помилки визначаються за формулами:

$\ddot{\mathrm{o}}=g_{i}+e_{i}$,

$\varnothing=g_{i} S^{i-1}+e_{i} S^{i-1}$.

Для того, щоб обидва синдроми помилки збіглися необхідно один з них помножити на Sil- або виконати i-1 тактів зсуву в регістрі сигнатурного аналізатора. Кількість таких тактів зсуву синдрому $\psi$ покаже номер групи розрядів або номер пакета, в якому сталася помилка. У тому випадку, якщо синдроми не співпали, то можна зробити висновок про наявність помилки в декількох пакетах. 
Особливість передачі повідомлень пакетами по дейтаграммний каналу передбачає можливість використання пакетом свого окремого маршруту. При цьому пакети можуть бути доставлені абоненту в різний час і з різних напрямків. У тому випадку, якщо кожен пакет містить кодове слово для перевірки інформації, що передається, то цю перевірку можна виконувати негайно після прибуття пакета. Однак наявність перевірочних слів в кожному пакеті, хоч і підвищує достовірність даних, що передаються, а й призводить до істотного збільшення надмірності інформації. Якщо мережа надійна і ймовірність виникнення помилки в пакеті або ймовірність втрати пакета не висока, то така надмірність не може мати підстав. Зниження надмірності можна домогтися шляхом використання двох перевірочних слів для всього повідомлення і здійснювати пошук помилок на основі виразу (10).

Використання такого підходу до визначення помилок в пакетах повідомлень призводить до зміни протоколу обміну даними. Протоколи обміну даними використовують зворотній звъязок для підвищення якості обслуговування трафіку, тому далі розглянемо процес передачі і прийому повідомлень на прикладі зворотнього зв язку. Алгоритм обробки повідомлення наведений на Рисунку 1.

Результатом алгоритмуможе бути висновок про правильне надходження повідомлень, про виникнення помилки в повідомленні. При цьому якщо помилка виникла в одному пакеті, то надсилається квитанція про необхідність його повторення і визначається проблемний маршрут, по якому цей пакет слідував.

Якщо помилка виникла в декількох пакетах, то надсилається квитанція про необхідність повторення всього повідомлення і збирається інформація про маршрути проходження пакетів для подальшого діагностування мережі.

У процесі прийому безлічі повідомлень різного розміру з різною кількістю і довжини пакета сигнатурний аналізатор повинен працювати в режимі поділу часу. Для обробки кожного з повідомлень необхідно виділяти фрагмент часу в залежності від довжини, кількості пакетів в повідомленнях і наявність їх у абонента. При цьому, відповідно до виразу (9), слід оперативно змінювати матрицю Si.

Оперативно отримати матрицю Si можна двома шляхами: використовувати памяять для зберігання матриць $\mathrm{Si}, \mathrm{i}=\{1 ; 2 ; . . . ; \mathrm{w}\}$; формувати матрицю $\mathrm{Si}$ в сигнатурному аналізаторі. В обох випадках слід використовувати елемент (наприклад, регістр) для тимчасового зберігання матриці. Якщо в основу побудови сигнатурного аналізатора використовуються поліноми ступенем $\mathrm{n}=16$ і більше, то в пристрої необхідний регістр з більш ніж в 256 розрядів

Розглянемо, як можна зменшити складність сигнатурного аналізатора шляхом формування матриці $\mathrm{Si}$ на прикладі полінома:

$$
P(x)=x^{4} \oplus x^{3} \oplus 1 \text {. }
$$

Для цього наведемо кілька ступенів цієї матриці в Таблиці 1.

Різні ступені матриці переходу S можна згенерувати двома способами:

Шляхом формування стовпців.

Шляхом формування рядків.

При першому способі утримання кожного стовпця матриці будь-якого ступеня можна отримати шляхом зсуву іншого стовбця в аналізаторі [4].

Наприклад, в матриці $S^{0}$ перший стовпець отриманий шляхом зсуву четвертого стовпця, другий першого, а третій - другого стовпця. Аналогічної особливістю володіють всі інші міри матриці. 


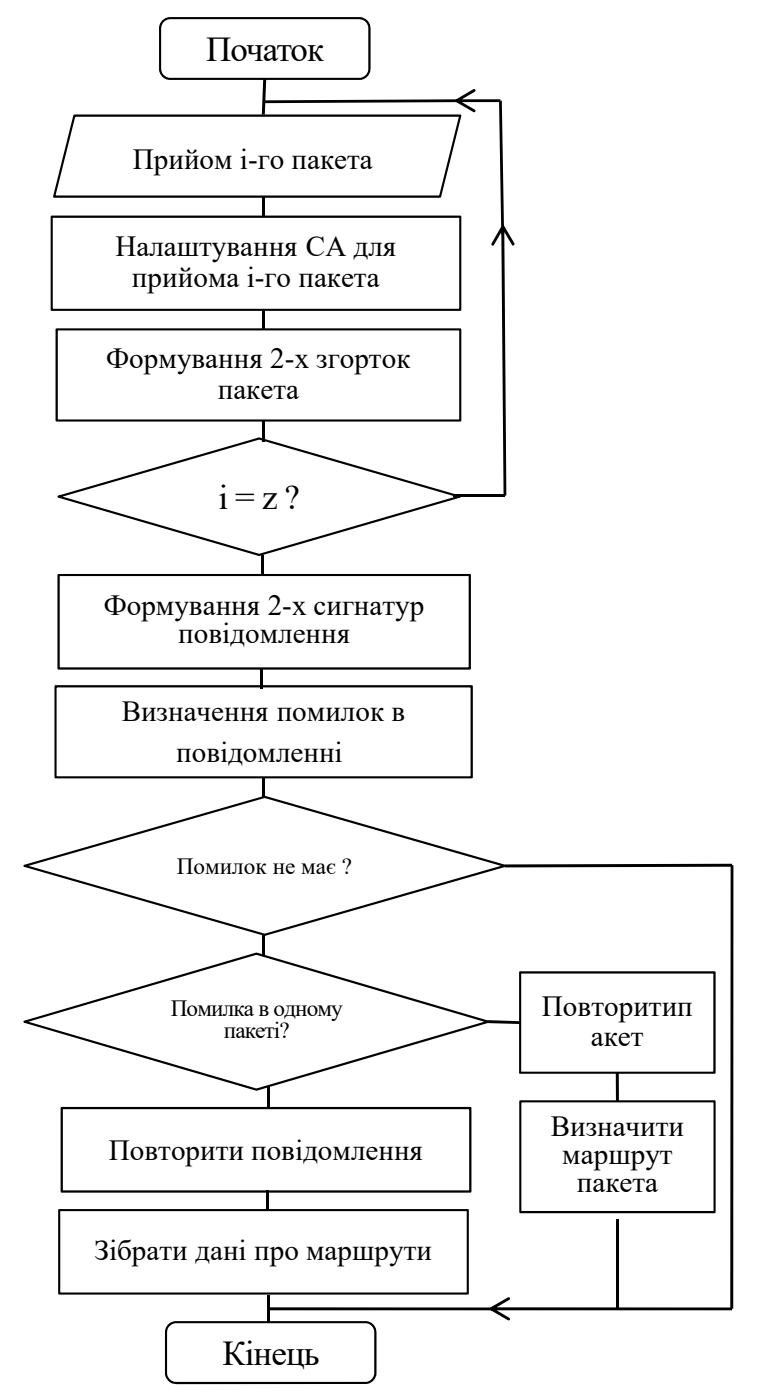

Рисунок 1. Алгоритм обробки повідомлення

Таблиця 1. Ступені матриці $\mathrm{S}$, відповідної поліному $P(x)=x^{4} \oplus x^{3} \oplus 1$

\begin{tabular}{c|c|c|c|c|c|c}
\hline S & S2 & S3 & S4 & S5 & S6 & S7 \\
\hline 0011 & 0110 & 1100 & 1011 & 0101 & 1010 & 0111 \\
1000 & 0011 & 0110 & 1100 & 1011 & 0101 & 1010 \\
0100 & 1000 & 0011 & 0110 & 1100 & 1011 & 0101 \\
0010 & 0100 & 1000 & 0011 & 0110 & 1100 & 1011 \\
\hline
\end{tabular}

На Рисунку 2 наведено генератор формування стовпців матриці в -7ми розрядному регістрі. На Рисунку 2 зображений регістр зсуву і два суматора за модулем два. Зворотні зв>язки з розрядів регістра підключені до входів першого суматора відповідно до коефіцієнтів полінома (12). 3 входами другого суматора з`єднані розряди регістра відповідно до коефіцієнтів зворотнього поліному (12):

$P_{o}(x)=x^{4} \oplus x \oplus 1$. (13)

Поліноми $\mathrm{P}(\mathrm{x})$ і Ро(x) мають одну і ту ж матрицю станів Н. Тому зрушення інформації в регістрі в одну або в іншу сторону дозволить збільшувати (зменшувати) ступінь матриці переходу S. У початковому стані в регістр зсуву записується код матриці $S^{0}(1000100)$. 


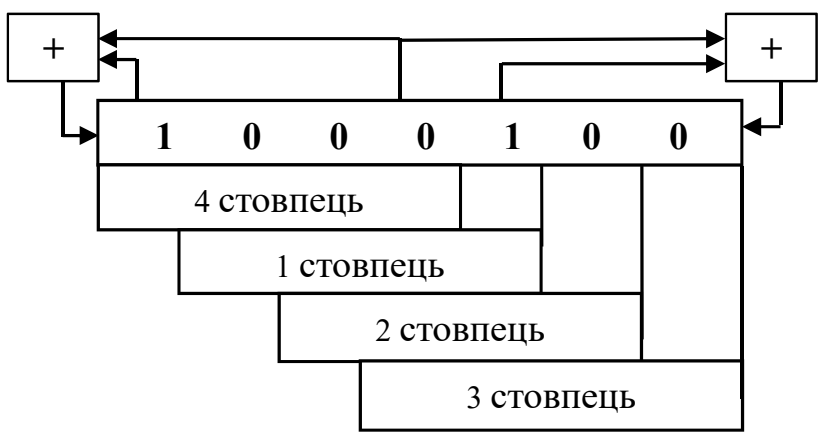

Рисунок 2. Генератор формування ступенів матриці переходу $\mathrm{Si}$

При другому способі формування ступенів матриці переходу Si зміст кожної ј-го рядка матриці будьякого ступеня можна отримати шляхом копіювання (j-1)-го рядка матриці зі ступенем на одиницю менше заданої (Таблиця 1). Перша стрічка і-го ступеню матриці формується шляхом зсуву у напряму молодших розрядів першої стрічці (i-1)-го ступеню матриці в тому випадку, коли в старшому розряді першої стрічр ці буде отриманий 0 . Якщо в старшому розряді першої стрічці i-го ступеню супроводжуючої матриці $\mathrm{S}^{\mathrm{i}}$ буде отримана 1 , то розряди що відповідають ступеням утворюючого поліному додатково інвертуються.

Використання різних поліномів в одному пристрої розширює його функціональні можливості. При цьому виникає необхідність тимчасового зберігання матриці переходу $\mathrm{Si}$ в регістрі розміром $\mathrm{n}$ * $\mathrm{n}(256$ розрядів, якщо $\mathrm{n}=16)$. При цьому виникає ще одне завдання оперативного формування матриці станів Н аналізатора відповідно утворюючого полиному.

Для виконання цієї функції також можна використати класичний генератор псевдовипадкової послідовності [2], який формує стовбці матриці станів шляхом зсуву коду 1000. Генератор псевдовипадкової послідовності містить регістр зсуву та суматор за модулем два, що з’єднані відповідно поліному циклічного коду. Сигнатурний аналізатор [13] побудований за такою ж схемою. Пристрій [2] здатний зберігати лише один стовпчик матриці станів. У процесі формування псевдовипадкової послідовності необхідно зберігати більше стовбців, особливо якщо кількість розрядів регістра буде більше ступеня полінома n. Наприклад, код побудований відповідно поліному (12) і наведений нижче дозволяє зберігати вісім стовбців матриці станів:

У наведеному коді, за аналогією з Рисунком 2, перші чотири розряди 0001 являють собою перший стовпець матриці станів $\mathrm{H}$, другі чотири розряди 0010 - другий стовпець, а (останні) чотири розряди 1010 - восьмий стовпчик.

Слід відмітити, що у стовбці 1 другий, третій та четвертий розряди можуть мати тільки нульове значення. У стовбці 2 нульові значення зберігають розряди 3 та 4, а у стовбці 3 - розряд 4. Якщо відкинути нульові розряди першого стовпчика, то отримаємо регістр, який містить тільки вісім розрядів. При цьому регістр зберігає вісім стовпчиків матриці станів, а в старшому розряді записується 1.

\section{4. РЕЗУЛЬТАТИ}

Аналогічно створюється пристрій на підставі любого характеристичного поліному. При цьому регістр для зберігання матриці станів буде мати стільки розрядів, скільки сигнатурний аналізатор має інформаційних входів.

В якості експерименту розглянемо синтез генератора формування ступенів матриці Si для наступного полінома: 
$P(x)=x^{16} \oplus x^{12} \oplus x^{9} \oplus x^{7} \oplus 1$

Наведемо кілька ступенів матриці переходу S для полінома (14) в Таблиці 2. Виходячи з даних Таблиці 2 , процес побудови генератора формування ступенів матриці Si за стовпцями зазнає суттєвих змін. Слід звернути увагу на зміну даних в стовпчиках, відповідних одиничним коефіцієнтами полінома (14). При цьому, починаючи з 7-го, 9-го і 12-го стовпців, виконується нова генерація інформації шляхом зсуву даних в регістрі [3].

В даному випадку для подання 256 розрядів ступенів матриці Si потрібно три регістра. Ці регістри формують такі стовпці матриці:

1. Перший регістр формує з першого по сьомий стовпець, а також з 13-го по 16-й стовпці.

2. Другий регістр зсуву формує восьмий і дев ятий стовпці.

3. Третій регістр - $3-10$ го по -12й.

Таблиця 2. Ступені матриці $\mathrm{S}$, що відповідає поліному $P(x)=x^{16} \oplus x^{12} \oplus x^{9} \oplus x^{7} \oplus 1$

\begin{tabular}{|c|c|c|}
\hline $\mathrm{s} 1$ & S2 & S7 \\
\hline 0000001010010001 & 0000010100100010 & 1010010001000000 \\
\hline 1000000000000000 & 0000001010010001 & 0101001000100000 \\
\hline 0100000000000000 & 1000000000000000 & 0010100100010000 \\
\hline 0010000000000000 & 0100000000000000 & 0001010010001000 \\
\hline 0001000000000000 & 0010000000000000 & 0000101001000100 \\
\hline 0000100000000000 & 0001000000000000 & 0000010100100010 \\
\hline 0000010000000000 & 0000100000000000 & 0000001010010001 \\
\hline 0000001000000000 & 0000010000000000 & 1000000000000000 \\
\hline 0000000100000000 & 0000001000000000 & 0100000000000000 \\
\hline 0000000010000000 & 0000000100000000 & 0010000000000000 \\
\hline 0000000001000000 & 0000000010000000 & 0001000000000000 \\
\hline 0000000000100000 & 0000000001000000 & 0000100000000000 \\
\hline 0000000000010000 & 0000000000100000 & 0000010000000000 \\
\hline 0000000000001000 & 0000000000010000 & 0000001000000000 \\
\hline 0000000000000100 & 0000000000001000 & 0000000100000000 \\
\hline 0000000000000010 & 0000000000000100 & 0000000010000000 \\
\hline S8 & $\mathrm{S} 14$ & $\mathrm{~S} 15$ \\
\hline 0100101000010001 & 1010100001110010 & 0101001001110101 \\
\hline 1010010001000000 & 0101010000111001 & 1010100001110010 \\
\hline 0101001000100000 & 1010101101010100 & 0101010000111001 \\
\hline 0010100100010000 & 0101010110101010 & 1010101101010100 \\
\hline 0001010010001000 & 0010101011010101 & 0101010110101010 \\
\hline 0000101001000100 & 1001010000100010 & 0010101011010101 \\
\hline 0000010100100010 & 0100101000010001 & 1001010000100010 \\
\hline 0000001010010001 & 1010010001000000 & 0100101000010001 \\
\hline 1000000000000000 & 0101001000100000 & 1010010001000000 \\
\hline 0100000000000000 & 0010100100010000 & 0101001000100000 \\
\hline 0010000000000000 & 0001010010001000 & 0010100100010000 \\
\hline 0001000000000000 & 0000101001000100 & 0001010010001000 \\
\hline 0000100000000000 & 0000010100100010 & 0000101001000100 \\
\hline 0000010000000000 & 0000001010010001 & 0000010100100010 \\
\hline 0000001000000000 & 1000000000000000 & 0000001010010001 \\
\hline 0000000100000000 & 0100000000000000 & 1000000000000000 \\
\hline
\end{tabular}


Початковий стан регістрів повинно відповідати матриці $S \cdot$. На Рисунку $ґ$ наведено перший регістр генератора формування ступенів матриці переходу $\mathrm{Si}$.

Для оперативного зменшення ступеня матриці, за аналогією з Рисунку 2, можна використовувати зворотній поліном (14):

$$
P_{o}(x)=x^{16} \oplus x^{9} \oplus x^{7} \oplus x^{4} \oplus 1 .(15)
$$

Таким чином, перший регістр містить 26 розрядів. Аналогічно будуються регістри для зберігання інших стовпців. Другий регістр буде містити 17 розрядів, а третій - 18 розрядів. Всього для зберігання матриці використовується 61 розряд замість 256.

Архітектура багатоканального сигнатурного аналізатора приведена на Рисунку 4. На малюнку введено такі позначення: БЗП - буферне запам ятовуючий пристрій, ПЗП - постійне запам>ятовуючий пристрій, БПСІ - блок просторового стиснення інформації, ГФМІ - генератор формування матриці Si, БМДI - блок множення даних на матрицю Si, БМД1 - блок множення даних на матрицю S1, БВП - блок визначення помилок, ОП - оперативна пам>ять.

Прийом і обробка інформації може виконуватися словами в залежності від розміру пакета і кількості входів аналізатора. У процесі прийому безлічі повідомлень сигнатурний аналізатор повинен працювати в режимі поділу часу. У цих умовах необхідно оперативно зберігати в блоці ОП і відновлювати контекст повідомлення.

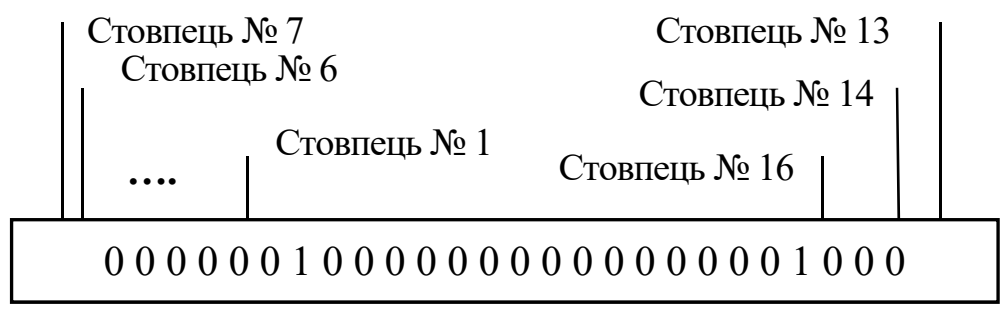

Рисунок 3. Перший регістр генератора формування ступенів матриці переходу $\mathrm{S}^{\mathrm{i}}$

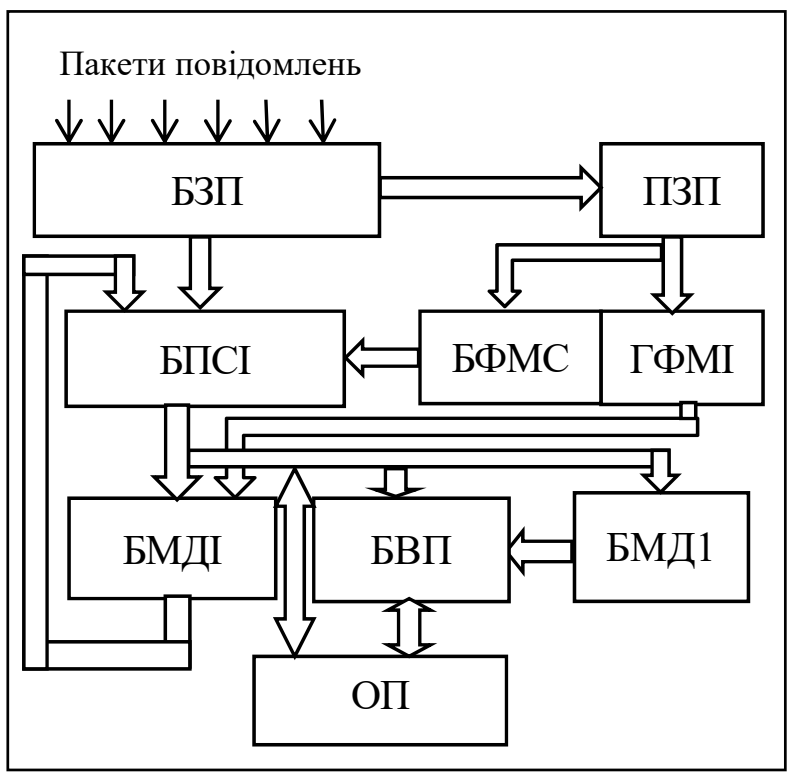

Рисунок 4. Архітектура багатоканального сигнатурного аналізатора 


\section{5. ОБГОВОРЕННЯ}

Визначимо, наскільки швидко можна виконати перевірку групи повідомлень одноканальним i багатоканальним сигнатурними аналізаторами. Час перевірки будемо вимірювати кількістю тактів, які необхідні для перевірки повідомлень. Кількість тактів для перевірки групи фрагментів повідомлень одноканальним пристроєм можна визначити відповідно до виразу:

$$
\tau_{1}=\sum_{j=0}^{q} k_{j} z_{j}
$$

За допомогою багатоканального пристрою кількість тактів визначається за формулою:

$\tau_{2}=k_{1}+\sum_{j=1}^{q}\left|k_{j+1}-k_{j}\right|+\sum_{j=1}^{q} z_{j}$

де $\left|k_{j+1}-k_{j}\right|-$ кількість тактів при підготовці до перевірки фрагмента (j+1)-го повідомлення після переө вірки фрагмента ј-го повідомлення.

Розглянемо випадок, коли кількість тактів перевірки постійно і $\mathrm{z}_{j}=$ const $=z$. Найбільша кількість тактів для підготовки до перевірки (j+1)-го після перевірки ј-го повідомлення визначається за формулою:

$$
\left|k_{j+1}-k_{j}\right|=\mathrm{m}-1 \text {. }
$$

Тоді вирази (16) і (17) можна перетворити до вигляду:

$$
\tau_{1}=\mathrm{q} \cdot \mathrm{m} \cdot \mathrm{z} ; \tau_{2}=\mathrm{m}+(\mathrm{q}-1)(\mathrm{m}-1)+q \cdot z .
$$

Визначимо, наскільки довше одноканальний аналізатор виконує перевірку з q фрагментів повідомлень:

$$
\tau_{1}-\tau_{2}=\mathrm{q} \cdot(\mathrm{z}-1)(\mathrm{m}-1)-1
$$

Для того, щоб багатоканальне пристрій було більш ефективним ніж одноканальне, необхідним $\epsilon$ дотримання виразу:

$$
\mathrm{q} \cdot(\mathrm{z}-1)(\mathrm{m}-1)>1 .(21)
$$

Нерівність (21) справедливо у всіх випадках, якщо виконуються наступні умови: q $>1 ; \mathrm{z}>1 ; \mathrm{m}>1$. Таким чином, пропоновані багатоканальні пристрої будуть найбільш ефективним при перевірці безлічі повідомлень.

Архітектура пристрою і алгоритм його роботи передбачають необхідність зберігання даних для забезпечення обробки інформації. При цьому слід зберігати дані про матриці станів Н (перевірочної матриці) і про різні ступені матриці переходу S. Необхідність використання сукупності полиномов призводить до істотного збільшення обсягу пам>яті. Наприклад, багатоканальні пристрої [4, 11] при використанні р полиномов вимагають для зберігання інформації наступну кількість розрядів:

$\mathrm{R}=n^{2} \cdot p \cdot \mathrm{m}$. (22)

У загальному випадку пропонований підхід до синтезу багатоканальних сигнатурних аналізаторів дозволяє замість матриць H і S зберігати тільки перший рядок матриці S (поліном). У Таблиці 3 наведені результати порівняння двох пристроїв за обсягом необхідної пам〉яті. 
Таблиця 3. Порівняння необхідного обсягу пам'яті для зберігання ступенів матриці переходу S

Джерело: Складено на основі джерела [12].

\begin{tabular}{|c|c|c|c|c|}
\hline $\mathbf{n}$ & Кількість поліномів & Кількість входів пристрою & Об'єм пам'яті в (біт) & Об’єм пам'яті (біт) \\
\hline 8 & 2 & 8 & 1,024 & 16 \\
\hline 16 & 4 & 16 & 16,384 & 64 \\
\hline 16 & 6 & 32 & 49,152 & 96 \\
\hline 20 & 6 & 32 & 76,800 & 120 \\
\hline
\end{tabular}

\section{ВИСНОВКИ}

Запропонована в роботі архітектура сигнатурного аналізатора дозволяє контролювати дані по пакетам або групам пакетів. Оскільки група пакетів інформаційного повідомлення може оброблятися у міру їх прийому в буферному пристрої зберігання даних, то немає необхідності в існуванні процесу складання цього повідомлення. При цьому не обов язково чекати прибуття «спізнюються» груп пакетів. За результатами перевірки даних можна зробити висновок про наявність помилки в одному пакеті або помилка поширена по всьому повідомленням. У першому випадку визначається проблемний маршрут «зіпсованого» пакета, у другому - збирається інформація про стан мережі.

Пропонований підхід до синтезу пристроїв контролю даних найбільш ефективний при перевірці передачі безлічі повідомлень пакетами по дейтаграммний каналу в режимі поділу часу.

Багатоканальний сигнатурний аналізатор дозволяє контролювати декілька пристроїв, що мають різну кількість виходів, які потрібно перевіряти за один такт генератора імпульсів. При цьому можна домогтися зниження надмірності в переданих даних шляхом використання двох перевірочних слів для всього повідомлення.

У роботі детально розглянуті питання зниження апаратурною надмірності при зберіганні службової інформації, що забезпечує роботу пристроїв. При цьому можна домогтися багаторазового зменшення необхідного обсягу пам яті в порівнянні з існуючими пристроями. Як подальшого розвитку цієї роботи передбачається проведення досліджень стосовно до протоколів обміну даними і розробки алгоритмічного і програмного забезпечення пошуку помилок в повідомленнях.

\section{СПИСОК ЛІТЕРАТУРИ}

1. Bljejkhut, R. (1986). Теория и практика кодов, контролирующих ошибки [Teoryia y praktyka kodov, kontrolyruiushchykh oshybky] (576 p.). M.: Mir.

2. Djachenko, O. N., \& Zhuravel, A. P. (1993). Многоканальный сигнатурный анализатор [Mnogokanalnyj signaturnyj analizator] (Патент 1797118, Российская Федерация, Донецкий политехнический институт, МКИ G06F11/00). Retrieved from http://ea.donntu. edu.ua/bitstream/123456789/18366/1/AC\%201797118.pdf

3. Gordon, G., \& Nadich, H. (2006). Локализация несправностей в микропроцессорных системах при помощи шестнадцатеричных ключевых кодов [Lokalizatsiya nespravnostey v mikroprotsesornykh systemakh pry pomoshchy shestnadtsaterychnykh kliuchevykh kodov]. Elektronika, 5, 23-33.

4. Ivanov, M. A., Ajgozhiev, M. K., Levchuk, T. V., Chugunkov, I. V., \& Chulikov, D. M. (1999). Многоканальный сигнатурный анализатор [Mnogokanalnyj signaturnyj analizator] (Патент 2133057, Российская Федерация, Московский инженерно-физический институт, МКИ G06F11/00). Retrieved from http://ru-patent.info/21/30-34/2133057.html

5. Losev, Ju. I., Borovoj, V. I., \& Kurilko, V. Е. (2003). Методика присвоения приоритетности обслуживания сообщений в сети обмена данными [Metodika prisvoyeniya prioritetnosti obsluzhivaniya soobshcheniy v seti obmena dannymi]. Radioelektronni $i$ kompyuterni systemy, 4(4), 98-101.

6. Losev, Ju. I., Shmatkov, S. I., \& Rukkas, K. M. (2011). Методы и модели обмена информацией в распределенных адаптивных вычислительных сетях с временной параметризацией параллельных процессов [Metody i modeli obmena informatsiyey $v$ raspredelennykh adaptivnykh vychislitelnykh setyakh s vremennoy parametrizatsiyey parallelnykh protsessov] (204 p.). H.: HNU imeni V. N. Karazina.

7. Losev, Ju. I., Shmatkov, S. I., Rukkas, K. M., \& Shhebenjuk, V. S. (2011). Сравнительная оценка эффективности одномаршрутного и мультимаршрутного методов передачи сообщений [Sravnitelnaya otsenka effektivnosti odnomarshrutnogo i multimarshrutnogo metodov peredachi soobshcheniy]. Zbirnik naukovih prac Harkivskogo universitetu povitrjanih sil, 2(28), 132-135. 
8. Losev, Ju. I., Volovik, B. M., Dresvjankin, V. V., \& Losev, M. Ju. (1994). Автоматизация в сетях с коммутацией пакетов [Avtomatizatsiya v setyakh s kommutatsiyey paketov] (215 p.). K.: «Tehnika».

9. Losev, M. Ju., Glushenkov, S. O., Yevsyukov, M. S., Patrakeєv, I. M., \& Shostak, A. V. (2012). Аналізатор сигнатур паралельного потоку даних [Analizator signatur paralelnogo potoku danih] (Патент на корисну модель 74159, МКИ G06F11/00). Retrieved from http:/uapatents.com/11-74159-analizator-signatur-paralelnogo-potoku-danikh.html

10. Losev, M. Ju., Risovanij, O. M., Tarasov, O. V., \& Shostak, A. V. (2012). Багатоканальний сигнатурний аналізатор з локалізацією помилок [Bahatokanalnyy syhnaturnyy analizator z lokalizatsiyeyu pomylok] (Патент на корисну модель 68273, МКИ $\mathrm{G} 06 \mathrm{~F} 11 / 00$ ). Retrieved from http://uapatents.com/10-68273-bagatokanalnijj-signaturnijj-analizator-z-lokalizaciehyu-pomilok.html

11. Novik, G. H., Sarychev, K. F., Avdeeva, L. E., \& Bykova, N. A. (1993). Параллельный сигнатурный анализатор [Parallelnyj signaturnyj analizator] (Патент 2001429, Российская Федерация, Научно-исследовательский институт электромеханики, МКИ G06F11/00).

12. Piterson, U., \& Ueldon, Е. (1986). Коды, исправляющие ошибки [Kody, ispravlyayushchiye oshibki] (590р.). M.: Mir.

13. Ponomarenko, V. S. (2014). Информационные системы в управлении, образовании, промыцилености [Informatsionnyуе sistemy v upravlenii, obrazovanii, promyshlennosti] (376 p.). H.: TOV «Shhedra sadiba pljus».

14. Ponomarenko, V. S. (2018). Інформаційні технологіï: сучасний стан та перспективи [Informatsiyni tekhnolohiyi: suchasnyy stan ta perspektyvy] (pp. 102-118). H.: Vid-vo TOV «DISA PLJuS». 